\title{
Festival Space: gender, liminality and the carnivalesque
}

Purpose - Contemporary outdoor rock and popular music festivals offer liminal spaces in which event participants can experience characteristics associated with the carnivalesque. Festival goers celebrate with abandonment, excess and enjoy a break from the mundane routine of everyday life. The aim of this conceptual paper is to explore the way gender is negotiated in the festival space.

Design/methodology/approach - The rock and popular music tribute festival, known as 'Glastonbudget' provides the focus for this conceptual paper. A pilot ethnographic study at the event utilising photographic imagery was used to understand the way in which gender is displayed.

Findings - It is suggested that liminal zones offer space to invert social norms and behave with abandonment and freedom away from the constraints of the everyday but neither women nor men actually take up this opportunity. The carnivalesque during Glastonbudget represents a festival space which consolidates normative notions of gender hierarchy via a complicated process of othering.

Research limitations/implications - This is a conceptual paper which presents the need to develop social science based studies connecting gender to the social construction of event space. The ideas developed in this article need to be further explored further building upon the research design established here.

Originality/value - There is currently a paucity of literature surrounding the concept of gender within these festival spaces especially in relation to liminality within events research.

Keywords - Festival; carnivalesque; liminality; fantasy; gender; events.

Paper type - Conceptual paper 


\section{Gender in Festival Spaces}

There has been a call for further exploration into the socio-cultural aspects of events and festival spaces (Mair and Whitford, 2013) in acknowledgement of the limited topics covered in events research to date (Kim et al., 2013). Of particular paucity is literature surrounding the conceptualisation and understanding of festival spaces and their relationship to gender which this article seeks to address. In Gilmore's (1998, p.2) exposé of carnival and culture he explains that gender is understood as 'the ways in which men and women interact in the social encounters of everyday life.' These encounters can be steeped in cultural and social assumptions. Connell (1987) argues that all forms of femininity are based around the overall subordination of women to men. Furthermore, it was Connell (1982) who first coined the phrase hegemonic masculinity to indicate that both gender and class are governed by multiple hierarchical relations. This term has become synonymous with research surrounding gender and feminism and does connect to the way gender manoeuvres in festival spaces. In later work, Connell and Messerschmidt (2005) explain that hegemony works through the creation of idealistic examples of masculinity and suggest the concept needs to provide a holistic view of gender hierarchy to recognise the agency of both dominant and subordinated groups when forming gender dynamics. The way in which gender hierarchies and social encounters are negotiated and positioned within festival sites will be of importance to this paper.

It is essential that socio-cultural implications of events and the investigation of event spaces are examined in order to better understand the way individuals interact and engage with events. It is perceived that varying spatial locations harbour differing gender relationships (Walby, 1997) and gender difference is prominent within 
contemporary society; where it is assumed men and women have 'different bodies, different capabilities, and different needs and desires' (Holmes, 2007, p.1). Further to this, it has been argued that gender stereotyping has been historically ubiquitous within events (Andrews and Leopold, 2013). This article seeks to unpack the relationship between this notion of gender difference and stereotyping whilst positioned within the supposed status-free refuge of liminality (Turner, 1969) and the carnivalesque. Liminality can be taken to mean the socially defined area which allows individuals to experience freedom from the mundane existence of everyday life (Shields, 1990). This can also include absorption into fantasy worlds (Light, 2009) or the physical and emotional sanctuary of 'transitional dwelling spaces' (Shortt, 2015, p.636). The carnivalesque describes abandonment, festivity and changes in normative hierarchical power structures (Bakhtin, 1984) which arguably are in situ within contemporary festival environments.

West and Zimmerman (1987, p.147) refer to gender as a 'powerful ideological device' which produces and also reproduces the freedoms and constraints that are determined by sex categorisation. It is thought that doing gender is about more than performing a static role (Fasting, 2004) but actually displaying gender variance. Gender here is not a biological, essentialist component but actually something which can be moulded, sculpted and changed depending on context and social surrounding. The concept of multiple identities is consistent with poststructuralist theorists such as Butler (1993) who subscribe to the view that identities are multiple, fluid and ever-changing. In Butler's notion of performativity, gender is understood as the repetition of multiple acts without one stable, singular explanation (Butler, 1999). In this sense, gender 
identities are moveable and dynamic and gender performance is compiled of many shifting ways of being a women or man.

It has been argued that hegemonic masculinities are of the highest status and this belief perpetuates to subordinate others (Hinojosa, 2010). Literature surrounding the carnivalesque and liminality often refers to the subversion of hierarchies and status which must be assumed to relate to gender hierarchies amongst others. During the Whitby Goth Festival, existing gender structures are reversed and temporarily deconstructed (Goulding and Saren, 2009). Therefore, within liminal spaces it is expected that inequalities will disperse and status based on normative gender beliefs will also disappear temporarily. Gender is an area of research that is yet to be adequately explored in relation to events and specifically music festivals. However, gender features so centrally in festival environments because its attraction to all gender variants; therefore the opportunity of festival goers to play at the edges of gender seems obvious (Tokofsky, 1999). Leisure spaces such as music festivals serve as sites for 'gender work' where femininities and masculinities are 'made' and re-constructed (Green, 1998, p.183). Some events are ranked in gendered ways (Andrews and Leopold, 2013) and it is thought men and women have differing roles in the festival environment (Picard, 2006). Although, festival practices have been known to consolidate and recycle dominant normative power relations, rather than appease them (Sharpe, 2008). This was certainly the case in Hubbard's (2013) exploration into Carnage! and the carnivalesque in relation to the body and anti-social behaviour. It was noted that women who took part in Carnage! 'conformed to ideals of sexual passivity, participating as objects, not subjects' (p.273) in the process. For these reasons, festivals 
are a significant site for the investigation of gender performance as they amalgamate leisure experiences in a social, dynamic and public environment.

\section{Carnivalesque, Liminality and the Contemporary Festival Landscape}

Festivals originate from religious and spiritual rituals and gatherings of people (Ravenscroft and Matteucci, 2003) which often involved celebration (Sharpe, 2008), food, drink, excess and fancy-dress. These characteristics are very similar to those expected to see at a contemporary outdoor musical festival and therefore the notion of carnivalesque is an important one within this article. Bakhtin (1984) describes the change in high and low hierarchical structures during carnival time, which do not simply invert but are blurred and merged (Weichselbaumer, 2012). It is important to note that during the time of carnival transgression the higher status beings and the 'lowOthers' are inextricably linked and co-create their shared fantasy world (Stallybrass and White, 1986, p.5). Similarly to the description of liminality, Turner (1969, p.95) states 'liminal entities are neither here nor there' and instead occupy an in-between space, an unclear and hazy existence which blurs convention. It can be argued that both the carnivalesque and liminal spaces offer sites where convention and normality is blurred and the 'carnivalesque loosens the knots of power' (Shields, 1990).

According to Sharpe (2008, p.219) the 'light-heartedness' and jovial atmosphere absorbed by attendees at festivals is one of the main features which distinguishes festival events from other leisure events such as parades and sporting fixtures. However, other writers do not see a separation of the two and instead view festivals as ‘carnivalesque inversions of the everyday’ (Ravenscroft and Matteuicci, 2003, p.1) and perceive the act of play (Turner, 1987) as instrumental to both carnival and festival. It 
must be noted that carnival is not a place to negate the ordinary status and routines of daily life but actually provides very complex and contradictory sites of contestation (Gilmore, 1998). Festivals allow for a break from the everyday routine and instead offer an 'opportunity to honour the mystical and spiritual in shared community' (Jones, 2010, p.276). But more recently, the offerings to these shared communities are becoming highly commercialised, with a pressure on festival organisers to receive external sponsorship to meet vast stakeholder needs and increased funding (Finkel, 2010). Arguably, festival spaces are no longer about the mystical and spiritual but instead about sustainability and impact.

Commercialism aside, carnival participants and festival goers are said to enjoy 'moments of freedom' in public spaces (Aching, 2010, p.417) whereby some normative ideologies and social statuses are suspended temporarily. These can be likened to the consumer's quest for perfect moments in which the everyday is transformed into something more special, more fantastical (Beaven and Laws, 2008). However, it is acknowledged that the allowance for such carnivalesque and social freedom may actually be instrumental in maintaining and reinforcing social stability in the long-term by providing a temporary release for chaos (Aching, 2010; Ravenscroft and Matteucci, 2003). This relationship between manipulation and control has significant repercussions for understanding gender display within festival sites.

Bakhtin’s (1984) version of carnivalesque is criticised by Aching (2010) for overlooking the carnival participant's sense of agency but also ultimately acknowledges that absolute freedom, even within a celebratory environment does not exist. It is thought that once the festival comes to an end whether that be the close of a music 
festival or the end of a street parade, all social structures and norms are restored (Anderton, 2009). Eco et al., (as cited in Sebeok, 1984, p.6) share this sentiment and calls this theory of transgression false. For them, carnival can only exist as an ‘authorized transgression' where status is thought to be inverted but is actually hiding under a façade of social order and discipline. The authors liken the situation to the use of circuses to keep the crowds quiet and ordered; a presentation of chaos to in turn retain power and hierarchical control. In contemporary festival spaces 'power can be seen as "the rules of the game”, which both enable and constrain action' (Clarke and Jepson, 2011, p. 9). Power here may involve the balancing of political and financial needs with those of the local community and organisation.

As well as liberation from everyday life (Shields, 1990), liminality also connects fantasy and the manipulation of reality. In Light's (2009) research exploring tourists' experiences of fantasy play in Transylvania he found tourists were actively engaged in identity experimentation within the fantasy limen. Definitions of liminality and the carnivalesque have much cross-over, although an interesting separation between liminality and the carnivalesque is proposed by Shields (1990) who states that liminal zones can be exploited to make people think they are escaping the structures of everyday life when in fact they are not. For example, in Shortt's (2015) research about the way space is utilised by employees at a hairdressing salon, dwelling areas, such as stairwell, doorways and cupboards are made meaningful by staff that require back-stage reprise. However, the non-dominant spaces being used by employees are still under the control and authority of the management team and are arguably necessary to maintain the smooth running of the business. Whereas the carnivalesque concentrates on the central role of the individual and the agency they possess in order to engage and interact 
with their social surroundings (Shields, 1990). Therefore inversion comes from the individual who has control over the exploitation of their surrounding social world. Liminal spaces are arguably easier to manipulate and control than the slippery notion of carnivalesque. In practical terms, festival organisers are able to control the temporary abandonment festival goers experience as part of the limen but may find it difficult to manage a more dynamic, chaotic movement instigated by the festival goers in the form of carnivalesque celebration.

In recent decades the festival scene has deviated from its original, religious roots (Raj, et al., 2009), but the essence of ritual and make-believe continues to exist. Getz (2007) proposes the definition of festivals simply as ‘themed, public celebrations’ (p.31) but he goes on to question the authenticity of some events that have been inaccurately branded as festivals for commercial reasons. This commercialisation of contemporary festivals demonstrates the societal and political control present in supposed liminal spaces. A liminal zone created by transformed social spaces allow for more flexible social rules and changes in acceptance of non-traditional behaviours (Picard and Robinson, 2006). However, this liminal space in essence creates a barrier for the overflow of celebration and excess, people are confined to the festival space and ultimately these spaces "remain prime sites of governance and discipline” (Ravenscroft and Gilchrist, 2009, p.36). This juxtaposes the festival between celebratory chaos and a social vehicle employed to maintain order and discipline in the long term. Providing individuals liminal space to momentarily lose themselves and behave in a care-free manner promotes the ethos of chaos as limited, constrained and restrictive. This paradoxical situation is also present in Andrew's (2006) research whereby holiday 
resorts are perceived as sites of leisure but actually present barriers and restrictions with regards to consumption and enjoyment.

Contemporary pressures on festivals to source external funding and meet government social policies (Finkel, 2006) have arguably impacted upon the creativity of the festival scene. In essence this politicisation of the festival space can also be viewed and limiting and restrictive. Therefore the liminality that festivals offer can be viewed as a social tool which affords attendees a controlled space to escape to and be deviant within before returning back to normality. Furthermore, festivals have been consistently linked to resistance and social protest over the years but this increasing commodification of festivals makes them more difficult to act as appropriate platforms for social change (Sharpe, 2008). At first glance, the festival site may appear imbued with carnival abandonment but actually creative freedom and festival programming is being shaped by external funders and changing organisational pressures (Finkel, 2009).

Modern rock and popular outdoor music festivals can be viewed as event spaces which are used to instigate experiences associated with carnival time. The physical locality of the festival place helps to create a liminal zone in which festival goers can participate in the entire festival spectacle. This involves feasting, drinking to excess, masquerading and expressing abandonment; all characteristics which link the festival space with the performance of carnivalesque. However, this relationship is very complicated and the carnivalesque celebrations manifested in liminal spaces can create paradoxical connotations. This was certainly the case in Gilmore's $(1998,71)$ work who discusses the dualism connected to the two parodies of women during carnival. Firstly, transvestite men dressed as colcha-clowns and performed 'a parody of womanhood' and 
secondly as the more 'ferocious parodies' of female demons and witches. In this research women were a focal point during carnival time through both costume and carnival song and poetry, women are both chastised and redeemed via the two media of display. It seems the carnivalesque simultaneously provides a space for freedom and change but also links to social order and governance (Weichselbaumer, 2012; Aching, 2010).

Festivals can offer complete release for attendees and a chance for selfexpression through gender and dress (Goulding and Saren, 2009). However, it is debatable to what extent this self-expression is completely agency-led or rather socially constructed through the festival hierarchies. During Spanish Carnival approximately $80 \%$ of male masqueeraders dressed as women but a very small percent of women dressed as men (Gilmore, 1998). Women’s festival jobs included dance, choreography and cake selling whereas men were involved in the construction of the festival site (Picard, 2006). Data collected by McCabe (2006) between 2001 and 2004 demonstrates the different gender roles during a community festival, the men played the sport and the women followed their men and also looked after their children. It appears that the performativity of gender as outlined by Butler earlier does not allow for an understanding of gender in relation to festival hierarchies. It is debatable to what extent the view of gender as fluid and multiple assists in understanding how the 'very real structures of inequality’ oppress and marginalise (Besnier, 2015, p.23). Furthermore, how is the expression of abandonment, freedom and experimentation of gender identity within carnival-limen truly agency-led? This is conceptualised by Aching (2010) who believes carnival time represents the intensification of social antagonisms and not their absence. 


\section{Festival Site for Gender Analysis}

Since 2005 a Leicestershire farm has provided the setting for the 'World's best tribute festival' (Glastonbudget, 2013), known as 'Glastonbudget', parodying the wellpublicised festival of a similar name. Glastonbudget was chosen as the site for investigation for two reasons, firstly because similarly to the content being investigated Glastonbudget blurs reality with fantasy by staging tribute bands such as the Kins of Leon, Fillers and Antarctic Monkeys. By parodying another festival it offers a fantasy environment which mimics mainstream festival experience and in itself offers an inbetween site to investigate. Secondly, the researcher used the attendance at this festival as part of a 'hen do' as a vehicle to pilot an ethnographic exploration into the topic.

This paper is based on a pilot ethnographic study, qualitative in design with a focus to unlock the research area of gender and festival space with a view to assess the viability for further research. To raise consciousness of potential status regularities and irregularities in the festival environment, photographic imagery was chosen as a nonintrusive method to capture the ordinary functioning on festival goers. Dressed in attire themed around the iconic film Top Gun, the researcher became embedded in the festival landscape of masquerade, façade and playfulness. It is argued that a culture cannot be understood or learnt from the outside but instead must be examined from the inside (Pitney and Parker, 2009) which is why ethnography was utilised. Tedlock (2000, p.455) describes ethnographers as 'cross-dressers' taken to mean that the outsider researcher slowly learns about the insider's lives through the wearing of insider clothes and the acquisition of their language and behavioural norms. This was implemented in this research through the adornment of fancy-dress and the shared experience with other festival goers. 
Participant observation of this kind is viewed as valuable and appropriate to convey event experiences (MacKellar, 2013). The use of a camera in this environment was deemed natural and orthodox and therefore photo-taking was considered useful to the research. Researcher observations were recorded via photographic imagery which is deemed an accurate and valuable tool due to the 'critical eye of the camera' (Collier and Collier, 1986, p.5). Photographs provide sustained stills of festival environments which can both stir emotion and provide key discussion points. Three of the photographs taken during the 2013 festival will be used within this paper to further explore the way gender is negotiated within the festival space.

\section{Masquerading gender at the festival site}

The use of disguise, fancy-dress and masquerade was a prominent feature of gender performances in relation to celebration and carnival during the festival. The first photograph (see Figure 1) portrays an oversized costume of a skeleton, complete with an extremely large skull against the backdrop of a marquee drinks tent. Masks are seen as an instrumental way to express 'self-recognition and misrecognition' during carnival time (Aching, 2010, p.415) and this costume also falls into a fantasy limen (Light, 2009). It seems that the use of costume and fancy-dress is significant in the creation of the carnivalesque and to further establish the way in which festival is separated from reality.

Unlike Shortt's (2015) limited, unconventional, liminal dwelling spaces, the entire festival site is a transitory place for festival goers. The employees at Shortt's hairdresses used stairways and cupboards as liminal spaces of rest bite whereas Glastonbudget was 
more open and perceived to be an entire site for play, fantasy and excess. However it is argued that there cannot be fantasy without authority. Glastonbudget was still regimented and managed in terms of security on entrance, orderly separated gender queues for the toilets and a schedule of musical acts to perform. The topsy-turvy carmivalesque behaviours of the festival goers were still confined to a social system of event management and control.

Gender boundaries became blurred at Glastonbudget which provided a space for both women and men to invert and manipulate gender displays. The second photograph (see Figure 2) being used in this paper captures two men dressed head to toe in elderly women's clothes, including wigs, dresses and cardigans. Similarly to Ware's (2001) research festival time creates an important space for cross-dressing men who will wear wigs, dresses and lipstick and take on the comic role of la vieille femme (the old women). These observations are also in-line with the parody of the good mother depicted by men during Spanish carnival time as loving, caring but also domineering (Gilmore, 1998). Both men and women are confined to socially acceptable rules of behaviour and appearance within everyday society which idealises feminine women and masculine men. In everyday life individual gender identities can be formulated and defined by abiding by the limits of these two gender categories (Parets et al., 2011). Arguably, during Glastonbudget physical and social-cultural space is provided to festival goers to experiment with gender identities within the fantastical limen of excess and festivity. The very interesting observation at the festival was the noticeable high number of young men dressing as old women, a gender display far removed from them normally in terms of both gender and age. 
The concept of othering (Schwalbe et al., 2000) is an important one when trying to understand the differences in gender costume behaviour. Oppressive othering takes place when one group aims to dominate another by defining the other group as inferior in some capacity, perhaps morally or intellectually. When men dress-up as elderly women they are consciously or sub-consciously satirising the notion of 'woman' as comical, old, ugly, inferior and frail. During a gothic festival Goulding and Saren (2009, p.44) note,

'when goth men dress as women they do so with extreme confidence and even competitiveness, often with their performances of femininity overshadowing their female counterparts'.

It appears that the traditional view of male supremacy features heavily within festival spaces, it is argued that men dominate the performance of femininity in a way which marginalises women simultaneously. Even when women masquerade as men or as androgynous they are 'masking “up” as less marginal and more powerful figures' (Ware, 2001, p.242) thereby also contributing to the impact of othering.

At festival time bright and revealing clothes are worn by performers which would not have been appropriate elsewhere (Jaimangal-Jones et al., 2010) as observed at Glastonbudget.When exploring gender and costume it is very important to acknowledge how the body is portrayed within the festival space. Women used costume comically at Glastonbudget and in some cases this had sexualised undertones. The third photograph (see Figure 3) portrays two women dressed as American style police officers in short skirts, caps, leather gloves and a weapons belt. The body is arguably being used symbolically here in line with the concept of cosplay (costume and play) allowing participants to engage with the festival experience (Andrews and Leopold, 
2013). Women prefer to dress in conventionally feminine attire and enjoy fantasy costumes (Gilmore, 1998) which was evident at Glastonbudget. It could be argued that the American cops in this photograph are resisting traditional displays of femininity and instead demonstrating agency to express overtly sexual representations of women in positions of power. This is in-line with Baktin’s (1984) original discussion regarding the inversion of status and power; in this case women maintain power through individual agency and playful connectivity to authority dress.

However, women do not simply dress a certain way in order to be consumed by the male eye but instead may dress for their own satisfaction and potentially to impress other women. It has been documented that women gaze upon other women, similar to men but potentially for differing reasons such as body comparison (Hall et al., 2011). The complexity of this gender play deepens when ultimately the sexualised display of bodies as objects still places women in a subordinate position. Whether it is men or women consuming the provocative costume display it is still done in a way which places women as objects of desire or comparison. Therefore, even though it appears the festival provides space for carnivalesque characteristics to dominate, in effect socially acceptable values of gender hierarchies are maintained.

Many women at the festival were dressed in provocative outfits as to exaggerate their femininity and/or potential agency. One example of this being a woman dressed as a Playboy Bunny, demonstrating a level of porno-chic (Duits and van Zoonen, 2006) unsurprising in this 'body conscious' and 'highly sexualized world' (Pritchard and Morgan, 2010, p.133). The outfits of both men and women contribute to the festival experience and notion of the carnivalesque; further to this all costumes command the 
attention of the tourist gaze (Urry, 2002). The way in which cross-dressing and costume is used did have its limitations. No women were observed dressed as men at Glastonbudget, a similar finding to the festival researched by Goulding and Saren (2009). This may reflect the maintenance of the normative gender order; whereby anybody has the ability or skill to play at femininity through costume but masculine masquerade is out of reach to women. It could be argued that women did not want to be consumed by others' gaze when dressed in masculine ways. Despite the display of emotive and controversial costume being used it appeared that both women and men wore fancy-dress in comical and playful ways.

It seems costume is a very important social tool for both men and women in order to express their identities in the in-between space of the festival. However, men seem to use the liminal space to create a comic version of 'women' whereas women sometimes use it to accentuate their femininity and further reinforce gender hierarchies. Glastonbudget festival space can be likened to the circus in Eco et al's., work as a vehicle for social restraint (Sebeok, 1984). The circus involves the big top for performances, the fantasy world of role play and characterisation and the loss of inhibitions and excitement. However, the circus only exits in order to maintain and reinforce social order and social norms which in this instance are those attached to gender idealism. Gender displays are flaunted, inverted, over-emphasised and camouflaged at times during Glastonbudget. Ultimately though, some women were seen as consolidating traditional, sexualised displays of femininity, in-keeping with the notion of women as objects not subjects (Hubbard, 2013). Men played at the borders of fantasy and reality, dressing as old women but in turn maintaining a dominant status as men who were simply masquerading as women. By satirising the woman as mortal, 
elderly and aging the men did not compromise their masculinity as it was seen as a humorous and confident display of male freedom. Alternatively women dressing in provocative costume further consolidated their position as a tourist scene to be gazed upon. Festivals can be a site to test and resist traditional gender hierarchies (Ware, 2001) but this is done in a socially controlled and ideologically embedded way.

\section{Conclusion and Implications}

The photographic observations in this paper highlight the way gender is displayed through dress and costume within a festival space. It is argued that hegemonic masculinity dominates the festival scene by men who satirise old women in a playful but powerful relationship of othering and women who come under the onlooker's gaze through overtly sexualised portrayals of hetero-normativity. These discussions are consistent with Stallybrass and White (1986) who argue the inversion of low and high statuses are inextricably linked in the world of carnival fantasy. Namely, the gender continuum of femininity and masculinity in terms of dress-up and play is significant for the way festival goers experiment in event spaces. It could be stated that the status-free notion of liminality (Turner, 1969) is not applicable to gender hierarchies within the festival site. The power relations between men and women are culturally ingrained by the social structures apparent in society, and the festival space is just a microcosm of this social world and therefore conforms to these traditional expectations.

Gender identities are indeed being played with, manipulated and moulded by festival goers at Glastonbudget in a fantasy liminal space which offers carnivalseque freedoms of excess and bodily exposure. However, unlike Anderton’s (2009) research, societal rules and social norms seem to exist within the liminal space rather than simply 
being restored at the end. Therefore it is difficult to understand to what extend festival spaces can be said to actively resist and oppose gender norms and expectations. The discussions within this paper matter because they transcend so many complicated and under-researched areas such as gender, festival spaces and the power relationship between both. It is hoped this article will encourage further exploration into this field, as Mair and Whitford (2013) explain there is a need for more socio-cultural studies in events research. Festivals offer a specific social service in regards to a controlled liminal space for adults to experiment with abandonment and ecstasy. There are practical implications for event managers from this paper in terms of the way in which festival spaces are designed and created to allow for abandonment and festivity. Event managers must ask themselves and their fellow stakeholders to what extent is our event going to be a site for abandonment, excess and fantasy? Furthermore, the control repercussions of this will impact on the logistical concerns of security, medical provision and physical boundaries. Early discussions in this paper connected to the commercialisation of contemporary festivals and therefore it would be useful to see how gender and consumerism is affected by this in festival spaces. Being a pilot study means more research of this ilk is required, using perhaps an expanded ethnographic research design to further progress these initial ideas.

\section{References}

Aching, G. (2010), “Carnival time versus modern social life: a false distinction”, Social Identities: Journal for the Study of Race, Nation and Culture, Vol. 16. No. 4, pp. 415425.

Anderton, C. (2009), “Commercializing the carnivalesque: The V Festival and image/risk management”, Event Management, Vol. 12 No. 1, pp. 39-51. 
Andrews, H. (2006), “Consuming pleasures: package tourists in Mallorca”, in Meethan, K., Anderson, A and Miles, S. (Eds.), Tourism, consumption and representation: narrative of place and self, CABI, Wellingford, pp. 217-235.

Andrews, H. and Leopold, T. (2013), Events and the social sciences. Routledge, Oxon.

Bakhtin, M. (1984), Rebelais and his world. (H. Iswolsky, Trans.), Indiana University Press, Bloomington.

Beaven, Z. and Laws, C (2008), “'Never let me down again’: loyal customer attitudes towards ticket distribution channels for live music events: a netographic exploration of the US leg of the Depeche Mode 2005-2006 world tour”, in Robertson, M. and Frew, E. (Eds.), Events and festivals: Current trends and issues, Routledge, London, pp. 19-41.

Besnier, N. (2015), “Sluts and superwomen: the politics of gender liminality in urban Tonga”, Ethnos: Journal of Anthropology, Vol. 61 No. 1/2, pp. 5-31.

Butler, J. (1993), “Bodies that matter: on the discursive limits of 'sex”, Routledge, London.

Butler, J. (1999), “Gender trouble: feminism and the subversion of identity”, 10th anniversary edition, Routledge, New York.

Clarke, A. and Jepson, A. (2011), “Power and hegemony within a community festival”, International Journal of Event and Festival Management, Vol. 2 No. 1, pp. 7-19. Collier, J. and Collier, M. (1986), "Visual anthropology: photography as a research method", UNM Press, New Mexico.

Connell, R.W. (1982), “Class, patriarchy, and Sartre’s theory of practice”, Theory and Society, Vol. 11 No. 3, pp. 305-320. 
Connell, R.W. (1987), “Gender and power: society, the person and sexual politics”, Polity Press, Cambridge.

Connell, R.W. and Messerschmidt, J.W. (2005), “Hegemonic masculinity: rethinking the concept”, Gender and Society, Vol. 19 No. 6, pp. 829-859.

Duits, L., \& van Zoonen, L. (2006), "Headscarves and porno-chic: disciplining girls' bodies in the European multicultural society”, European Journal of Women's Studies, Vol. 13 No. 2, pp. 103-117.

Fasting, K. (2004), “Small country - big results: women’s football in Norway”, in Hong, F. and Mangan, J.A. (Eds.), Soccer, women, sexual liberation: kicking off a new era, Frank Cass Publishers, London, pp. 157-169.

Finkel, R. (2006), “Tensions between ambition and reality in UK combined arts festival programming: case study of The Lichfield Festival”, International Journal of Event Management Research, Vol. 2 No. 1, pp. 25-36.

Finkel, R. (2009), “A picture of the contemporary combined arts festival landscape”, Cultural Trends, Vol. 18 No. 1, pp.3-21.

Finkel, R. (2010), “Re-imaging arts festivals through a corporate lens: a case study of business sponsorship at the Henley Festival”, Managing Leisure, Vol. 15 No. 4, pp. 237-250.

Getz, D. (2007), Event studies: Theory, research and policy for planned events, Elsevier, Oxford.

Gilmore, D.D. (1998), Carnival and culture: sex, symbol, and status in Spain, Yale University Press, New Haven.

Glastonbudget. (2013), “Glastonbudget”, available at: http://www.glastonbudget.org (accessed 24 February 2015). 
Goffman, E. (1959), The presentation of self in everyday life, Penguin, Harmondsworth.

Goulding, C. and Saren, M. (2009), "Performing identity: an analysis of gender expressions at the Whitby goth festival”, Consumption Markets and Culture, Vol. 12 No. 1, pp. 27-46.

Green, E. (1998), “'Women doing friendship’: An analysis of women’s leisure as a site of identity construction, empowerment and resistance”, Leisure Studies, Vol. 17 No. 3, pp. 171-185.

Hinojosa, R. (2010), “Doing hegemony: military, men, and constructing a hegemonic masculinity”, The Journal of Men’s Studies, Vol. 18 No. 2, pp. 179-194.

Holmes, M. (2007), What is gender? Sociological approaches. Sage, London.

Jaimangal-Jones, D., Pritchard, A., and Morgan, N. (2010), “Going the distance: locating journey, liminality and rites of passage in dance music experiences”, Leisure Studies, Vol. 29 No. 3, pp. 253-268.

Hall, C., Hogue, T. and Guo, K. (2011), “Differential gaze behaviour towards sexually preferred and non-preferred human figures”, Journal of Sex Research, Vol. 48 No. 5, pp.461-469.

Hubbard, P. (2013), “Carnage! coming to a town near you? Nightlife, uncivilised behaviour and the carnivalesque body”, Leisure Studies, Vol. 32 No. 3, pp. 265-282.

Jones, C.C. (2010), “Playing at the queer edges”, Leisure Studies, Vol. 29 No. 3, pp. 269-287.

Kim, J., Boo, S. and Kim, Y. (2013), "Patterns and trends in event tourism study topics over 30 years”, International Journal of Event and Festival Management, Vol. 4 No. 1, pp. 66-83. 
Light, D. (2009), “Performing Transylvania: tourism, fantasy and play in a liminal space”, Tourist Studies, Vol. 9 No. 3, pp. 240-258.

Löw, M. (2006), “The social construction of space and gender”, European Journal of Women’s Studies, Vol. 13 No. 2, pp. 119-133.

MacKellar, J. (2013), "Participant observation at events: theory, practice and potential”, International Journal of Event and Festival Management, Vol. 4 No. 1, pp. 56-65.

Mair, J. and Whitford, M. (2013), “An exploration of events research: event topics, themes and emerging trends”, International Journal of Event and Festival Management, Vol. 4 No. 1, pp.6-30.

McCabe, S. (2006), “The making of community identity through historic festive practice: the case of Ashbourne Royal Shrovetide football”, in Picard, D. and Robinson, M. (Eds.), Festivals, tourism and social change: remaking worlds, Channel View Publications, Clevedon, pp. 99-118.

Parets, S., Levy M. and Galily, Y. (2011), “National and gender identity perceptions among female football players in Israel”, Soccer and Society, Vol. 12 No. 2, 228-248.

Picard, D. (2006), “Gardening the past and being in the world: a popular celebration of the abolition of slavery in La Reinion”, in Picard, D. and Robinson, M. (Eds.), Festivals, tourism and social change: remaking worlds, Channel View Publications, Clevedon, pp. 46-70.

Picard, D. and Robinson, M. (Eds.). (2006), Festivals, tourism and social change: Remaking worlds, Channel View Publications, Clevedon.

Pitney, W.A. and Parker, J. (2009), “Qualitative research in physical activity and the health professions”, Human Kinetics, Champaign. 
Pritchard, A. and Morgan, N. (2010), “'Wild On’ the beach: discourses of desire, sexuality and liminality”, in Waterton, E. and Watson, S. (Eds.), Culture, heritage and representation: perspectives on visuality and the past, Ashgate Publishing Ltd, Farham, pp. 127-144.

Raj, R., Walters, P. and Rashid, T. (2009), Events management: An integrated and practical approach, Sage, London.

Ravenscroft, N., \& Gilchrist, P. (2009), “Spaces of transgression: governance, discipline and reworking the carnivalesque”, Leisure Studies, Vol. 28 No. 1, pp. 35-49.

Ravenscroft, N., \& Matteucci, X. (2003), “The festival as carnivalesque: Social governance and control at Pamplona’s San Fermin fiesta”, Tourism, Culture \& Communication, Vol. 4 No. 1, pp. 1-15.

Schwalbe, M., Godwin, S., Holden, D., Schrock, D., Thompson, S. and Wolkomir, M. (2000), "Generic processes in the reproduction of inequality: an interactionist analysis", Social Forces, Vol. 79 No. 2, pp. 419-452.

Sebeok, T.A. (Ed,), (1984), “Eco, Ivanov and Rector: carnival! volume 64 of approaches to semiotics”, Walter de Gruyter, Berlin.

Sharpe, E.K. (2008) "Festivals and social change: intersections of pleasure and politics at a community music festival”, Leisure Sciences, Vol. 30 No. 3, pp. 217-234.

Shields, R. (1990), “The 'system of pleasure': Liminality and the carnivalesque at Brighton”, Theory, Culture and Society, Vol. 7 No. 1, pp. 39-72.

Shortt, H. (2015), “Liminality, space and the importance of 'transitory dwelling places' at work”, Human Relations, Vol. 68 No. 4, pp. 633-658.

Stallybrass, P. and White, A. (1986), The politics and poetics of transgression, Cornell University Press, New York. 
Tedlock, B. (2000), “Ethnography and ethnographic representation”, in Denzin, N. and Lincoln, Y. (Eds.), Handbook of qualitative research, 2nd edition, Sage Publications, London, pp.455-486.

Tokofsky, P. (1999), “Masking gender: A German carnival custom in its social context”, Western Folklore, Vol. 58 No. 3/4, pp. 229-318.

Turner, V. (1969), The ritual process: Structure and anti-structure, Aldine Transaction, London.

Turner, V. (1987), The anthropology of performance, PAJ Publications, New York.

Urry, J. (2002), The tourist gaze ( $2^{\text {nd }}$ ed.), Sage, London.

Walby, S. (1997), Gender transformations, Routledge, London.

Ware, C.E. (2001), “Anything to act crazy: Cajun women and Mardi Gras disguise”, Journal of American Folklore, Vol. 114 No. 452, pp. 225-247.

Weichselbaumer, D. (2012), “Sex, romance and the carnivalesque between female tourists and Caribbean men”, Tourism Management, Vol. 33 No. 5, pp. 1220-1229.

West, C. and Zimmerman, D.H. (1987), "Doing gender”, Gender and Society, Vol. 1 No. 2, pp. 125-151.

\section{List of Figures}

Figure 1. An example of costume at Glastonbudget 2013. Source: Author photo, $26^{\text {th }}$ May 2013. 
Figure 2. La vieille femme at Glastonbudget 2013. Source: Author photo $26^{\text {th }}$ May 2013.

Figure 3. Female authority figures at Glastonbudget 2013. Source: Author photo, $26^{\text {th }}$ May 2013. 